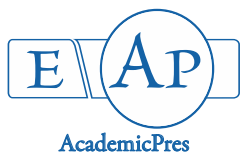

Jha KK et al. (2020)

Notulae Scientia Biologicae 12(1):124-142

DOI: $10.15835 / \mathrm{nsb} 12110547$

Research Article

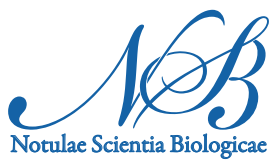

\title{
Vultures, their population status and some ecological aspects in an Indian stronghold
}

\author{
Kaushalendra K. JHA ${ }^{1 *}$, Michael O. CAMPBELL ${ }^{2}$, Radhika JHA ${ }^{3}$ \\ ${ }^{1}$ Indian Institute of Forest Management, Technical Forestry, Tropical Forest Ecosystem and Environment Management Unit, \\ Nehru Nagar, Bhopal, MP 462003, India; jhakk1959@gmail.com ("corresponding author) \\ ${ }^{2}$ Simon Fraser University, 8888 University Dr, Burnabay, BCV5A 1S6, Canada; ecol55@hotmail.com \\ ${ }^{3}$ Lucknow University, Zoology Department, University Road, Lucknow, India; jhakradhika@gmail.com
}

\begin{abstract}
Indian vultures have important ecological and socio-economic functions and are increasingly studied, per their ecological role and recently, their catastrophic populations' decline. However, there are few studies of vultures in central India, a vulture stronghold. The present paper examined the presence, distribution per landcover variation, roosting and nesting habits of vultures in this region. Both quantitative (total count) and qualitative (questionnaire survey) methods of research were applied. The hypotheses were that vulture presence is higher in forested areas, unaffected by agricultural development (excepting the Egyptian vulture); as well as that vultures are more likely to roost and nest in large trees and on cliffs in open landcover. Vulture species recorded in summer and winter counts were the Long-billed vulture (Gyps indicus, Scopoli, 1786), Egyptian vulture (Neophron percnopterus, Linnaeus, 1758), White-rumped vulture (Gyps bengalensis, Gmelin, 1788), Eurasian Griffon vulture (Gyps fulvus, Hablizl, 1783), Red-headed vulture (Sarcogyps calvus, Scopoli, 1786), Cinereous vulture (Aegypius monachus, Linnaeus, 1766) and Himalayan Griffon vulture (Gyps bimalayensis, Hume, 1869). Their average total abundance was of 7,028 individuals, maximum being Longbilled vulture (3,351) and minimum being Cinereous vulture (39). Thematic maps documented distributions in different agroclimatic regions and ecozones. Orography and forest structure influenced vulture presence, but human disturbance did not. Vulture protection, food monitoring and human-induced disturbances are manageable with critical, informed and flexible policies. These findings contribute to monitoring and management planning for vulture conservation in Central India and elsewhere.
\end{abstract}

Keywords: abundance; conservation; central India; habitat; vulture species

\section{Introduction}

Vultures are important for their scavenging role and socio-cultural and religious significance in India and elsewhere (Pain et al., 2003; Ogada et al., 2011; Moleon et al., 2014; Campbell, 2015). Gyps vultures, especially Indian White-backed vultures and Long-billed vultures, were common in India, Nepal and Pakistan until the 1990s (Thakur and Kataria, 2012). Numbers of these vulture species declined strongly over most of their historical range, largely due to the impact of the veterinary drug Diclofenac (Shultz et al., 2004; 
Prakash et al., 2007; Bonal and Prakash, 2014). This drug was later replaced with the less toxic compound Meloxicam, which influenced the stabilization of vulture populations in India and Nepal (Cuthbert et al., 2011; Bowden, 2012).

Northern India hosts larger populations of the nine vulture species than the Southern subtropical region (Naoroji, 2006). Resident species frequent forest, mountainous cliffs and sometimes agricultural landcover. Central India (Madhya Pradesh $=$ MP) has a large vulture population, due to the dual tropical and subtropical climates, suitable forest cover over plateaus, mountains and valleys, large cattle and wildlife populations. Vulture nests and roosts are on cliffs and in trees, the latter usually in open forests, sometimes near cultivated landcover. For example, the Griffon vulture is a colonial cliff nester (Campbell, 2015). Egyptian vultures are cliff nesters in heterogeneous landscapes (Mateo-Tomas and Olea, 2009). Cinereous vultures occur in open habitats, especially grassland, semi-desert, scrub and open forest in hilly and mountainous areas (Campbell, 2015).

The case study area (MP) is covered by subtropical wet and dry, tropical wet and dry, as well as semiarid climates. It is divided into six ecozones, using geographical indicators: Bundelkhand, Central, Chambal, Malwa, Satpura and Vindhyan Ecozones (AR MPSBB, 2007-08). It also comprises 11 agro-climatic regions, based on soil, climatic and cropping variations (Bundelkhand, Central Narmada Valley, Chhattisgarh Plain, Gird Region, Jhabua Hills, Kymore Plateau and Satpura Hills, Malwa Plateau, Nimar Valley, Northern Hill Region of Chhattisgarh, Satpura Plateau and Vindhyan Plateau) (Sharma et al., 2013).

The aim of the study was to generate reference data on Central India, which is a vulture stronghold (Jha, 2018). The data was derived by recording: (i) species richness and abundance of vultures; (ii) agroclimatic regions and ecozone distributions; (iii) correlations of past and current vulture populations; (iv) habitat frequencies of different vulture species; (v) breeding statuses of the resident vulture species; and (vi) local/seasonal movements of resident vultures.

\section{Materials and Methods}

Study site

Central India (MP, $21^{\circ} 6^{\prime}-26^{\circ} 30^{\prime}$ North and $74^{\circ} 00^{\prime}-82^{\circ} 51^{\prime}$ East) (Figure 1) is near the geographical center of India, contiguous with the former British Central Province, divided into several ecozones (Table 1). The tropical and sub-tropical climate is influenced by warm air masses from the Arabian Sea from the South and cold, high-altitude Himalayan air masses from North. The result is a mild subtropical climate, with a hot dry summer (March-June), monsoon rains (July-September) and a cool, relatively dry winter (OctoberFebruary). Rainfall averages about $1,370 \mathrm{~mm}$, deceasing from east $(2,150 \mathrm{~mm})$ to west $(1,000 \mathrm{~mm})$. Vegetation types are the dense tropical moist deciduous forest in the South, tropical dry deciduous forest in the middle and more open tropical thorn forests in the North, with undulating and hilly topography. The crown cover of these forests, respectively, are dominated by $>70 \%, 40-70 \%$ and $<40 \%$ density. Forests cover $28 \%$ of MP state, across varying topography, while $52 \%$ of the state is under agricultural landcover.

\section{Field survey}

MP forest department is divided into forest circles and further into forest divisions (FDs) or district level administrative units. All the FDs were surveyed and workshops on census protocol, data collection pro forma and species identification were held. An identification booklet of vulture species in MP (Jha, 2015b) was circulated. Preliminary surveys located historical vulture distributions, whereas current roosting and nesting sites were identified and later revisited for data collection. The population estimation protocol was circulated, and two vulture counts were undertaken in winter (23/01/2016) and summer (14/05/2016). All sightings at pre-decided sites (ascertained during preliminary survey) were counted. Dates were fixed to avoid double counting from bird movements. Count times were fixed between 7:00 h - 9:00 h in winter and 6:00 h 
126

- 8:00 $\mathrm{h}$ in summer, to ensure full counts. Species, adults and juveniles were identified. Roosting, nesting and bathing sites were recorded using a GPS system.

Different nest classifications have been used in the literature (Gilbert et al., 2006; van Beest et al., 2008; Bhusal, 2011; Joshi et al., 2015 etc.). In the current research, there were active nests (with adults and juveniles/chicks/eggs), inactive nests (occupied/ surrounded only by adults) and abandoned nests (unoccupied). This estimated the breeding, potentially breeding and non-breeding vultures. It was assumed that every active and inactive nest supported one pair of resident breeding vultures. Therefore, breeders, potential breeders and non-breeders were assessed, respectively, by using the formula of: (i) twice the active nests, (ii) twice the inactive nests, and (iii) remaining population out of total population of residents.

Coordinates were recorded using GPS and binoculars and cameras were used for bird identification and counts. Microsoft Word and Excel, ArcGIS and PRESENCE software was used for data compilation, analysis and map generation. Thematic maps depicting roosting and nesting locations and species distribution were prepared by using geographical coordinates. ArcGIS 10.3.1 was used to convert GPS readings to spatial data layers (point features providing the location). Vulture locations were overlaid on the state map. Various thematic figures were designed using the retrieval function. A questionnaire survey was conducted targeting the villagers and the forest guards for their knowledge on vulture ecology.
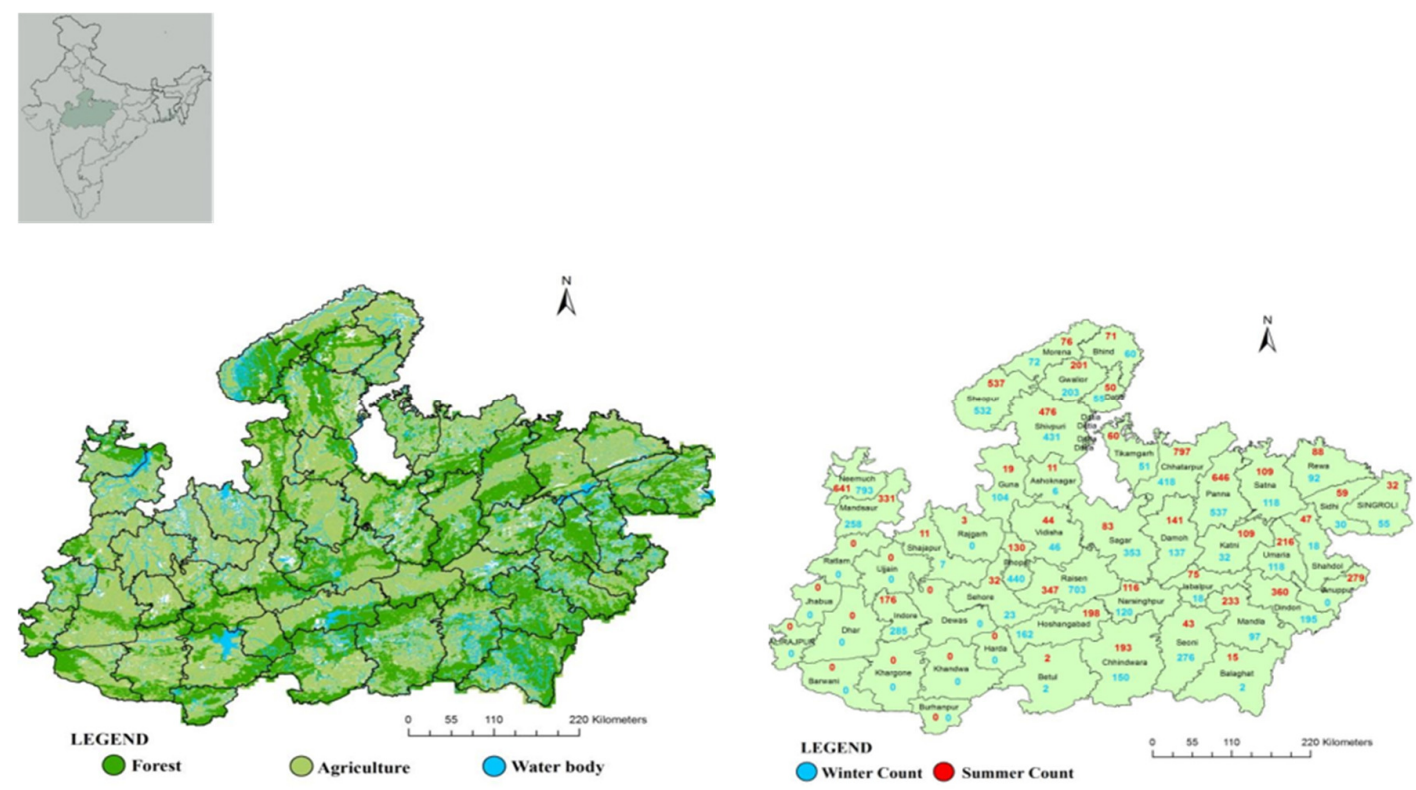

Figure 1. Location of the study area: Central India (Madhya Pradesh) with major Landcover; forest, agriculture and water bodies, on the left and numeric distribution of vultures in different districts, on the right. Inset gives relative position of the study area in India

Table 1. Climatic and physiographic characteristics of ecozones in the study area

\begin{tabular}{|c|c|c|c|c|c|}
\hline Ecozones & Temperature $\left({ }^{\circ} \mathrm{C}\right)$ & Rainfall $(\mathrm{mm})$ & Elevation $(\mathrm{m})$ & Forest type & River system \\
\hline Bundelkhand & $7.5-42.5$ & $800-1,400$ & $150-450$ & Dry Deciduous & Ken, Sonar, Berma, Tons \\
\hline Central & $5.1-42.5$ & $1,200-1,400$ & 300 & Moist/Dry Deciduous & Betwa, Narmada Tributaries \\
\hline Chambal & $1-47^{*}$ & $800-1,000$ & $15-300$ & Dry Deciduous & Chambal, Kalisindh, Parvati \\
\hline Malwa & $1.5-45^{* *}$ & $800-1,200$ & $350-450$ & Dry Deciduous & $\begin{array}{c}\text { Chambal, Mahi, Kshipra, Betwa, } \\
\text { Parvati }\end{array}$ \\
\hline Satpura & $10-39$ & $1,000-1,600$ & 300 & Moist/Dry Deciduous & $\begin{array}{c}\text { Tawa, Wainganga, Johila, } \\
\text { Denwa, etc. }\end{array}$ \\
\hline Vindhyan & $8-43$ & $1,200-1,600$ & $400-1,000$ & Moist/Dry Deciduous & Sone, Kanhar Tributaries \\
\hline
\end{tabular}

Note: elevation does not include peak height. ${ }^{*}$ and ${ }^{* *}$ are representative of Gwalior and Indore. 


\section{Vulture movement and sites}

Vultures movements relate to food and water sources hence movement zones were classified into water use areas and foraging areas. Qualitative methods (interview and questionnaire survey) were used to determine foraging ranges. Based on the responses, movement distance range from roost/nest to waterbody was $0.1 \mathrm{~km}$ to $13 \mathrm{~km}$ (average $1.66 \mathrm{~km} ; \mathrm{n}=2,277$ ) and from forest fringe or nest/roost to food source was 1 $\mathrm{km}$ to $45 \mathrm{~km}$ (average $7.7 \mathrm{~km}$; $\mathrm{n}=37$ ). Assuming that vultures travelled the same distance in all four directions, the figures were $11 \mathrm{~km}^{2}$ (water use area) and $237 \mathrm{~km}^{2}$ (foraging area). However, for convenience, sub-cells and cells of equal size, $10 \mathrm{~km}^{2}$ and $250 \mathrm{~km}^{2}$, respectively, were fixed to make a grid framework for the surface area of Madhya Pradesh (Figure 2) using fishnet tool of Arc GIS. The sub-cells were also considered as vulture sites embodying one to many sightings of roosts or nests with vultures within the area. Presence and absence of vultures during the census was recorded as 1 and 0 , respectively in the sub grids and occupancy analysis was done using "PRESENCE" software.
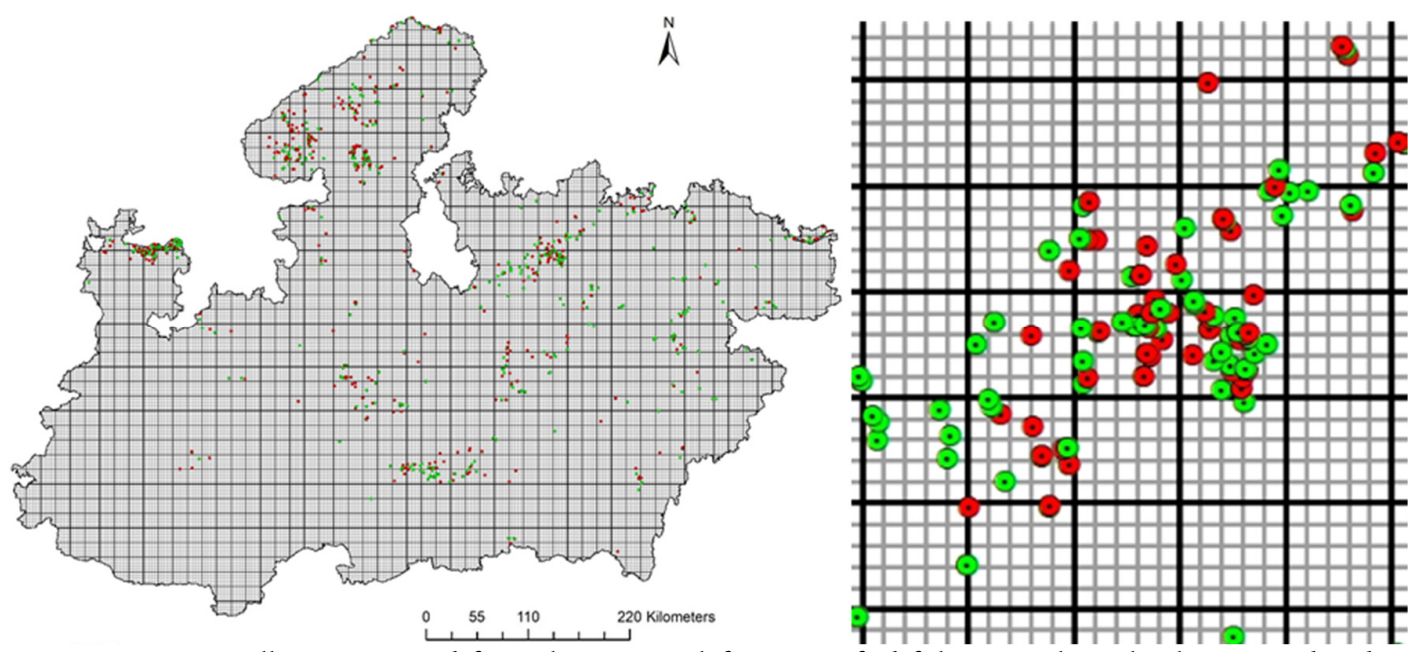

Figure 2. Small area extracted from the state on left is magnified fishnet on the right showing red and green circles are winter and summer sighting points of vultures. Black squares are grids of $250 \mathrm{~km}^{2}$ and grey squares are sub-grids of $10 \mathrm{~km}^{2}$. These grey and black squares are assumed shelter sites and foraging sites in the study area

\section{Results}

The questionnaire survey and quantitative work, recorded people's observations and understanding of vulture ecology, while recording sites, nests and vulture presence, as listed below.

Questions concerned vulture species type, nesting tree species, reasons for vulture decline etc. Respondents returned 2,103 completed questionnaires, out of 2,275 expected ones ( $92.4 \%$ return). Data analysis revealed the respondents identified vulture species with indicators. Firstly, while $20 \%$ of the respondents saw no vultures, 39\%, 15\%, 10\%, 9\%, 5\% and 1\% each identified Long-billed vulture (LV) Gyps indicus, Egyptian vulture (EV) Neophron percnopterus, White-rumped vulture (WV) Gyps bengalensis, Redheaded vulture (RV) Sarcogyps calvus, Cinereous vulture (CV) Aegypus monachus, Himalayan griffon (HG) Gyps himalayensis and Eurasian griffon (EG) Gyps fulvus, respectively. Secondly, 91\% of the respondents acknowledged the local vulture population had either declined or become extinct. Thirdly, a majority (51\%) blamed the use of diclofenac, $24 \%$ blamed food scarcity, $16 \%$ cited deforestation and $9 \%$ gave other reasons (aircraft collisions, natural disaster, sun radiation). Hearsay, rather than scientific information, dominated perceptions on diclofenac. Fourth, the respondents ranked vulture habitats as trees (28\%), cliffs/mountains 


\section{8}

(25\%), water bodies (13\%), agricultural fields (8\%), slaughter houses/dump yards (3\%), old-monuments (2\%) and towers $(21 \%)$. Fifth, the respondents cited relevant tree species used by vultures. These were Peepal (Ficus religiosa) (25\%), Banyan (Ficus benghalensis) (20\%), Arjun (Terminalia arjuna) (14\%), Semal (Bombax ceiba) (12\%), Tamarind (Tamarindus indica) (7\%), Haldu (Haldina cordifolia) (5\%) and both Sheesham (Dalbergia sisso) and Mango (Mangifera indica) (1\%). The remaining respondents (13\%) identified other trees, including Chitwan (Alstonia scholaris), Keekar (Acacia nilotica), Saja (Terminalia tomentosa), Palash (Butea monosperma), Sagaun (Tectona grandis) and Eucalyptus (Eucalyptus globulus). Sixth, the respondents listed carcass disposal methods as outside the village boundary (79\%), burial of carcasses (11\%), sale to slaughter houses $(6 \%)$ and railway tracks, roadsides or in the forest (4\%). Seventh, respondents identified competing scavengers as dogs (44\%), crows (41\%) and other species (15\%) (e.g. egrets, jackal, myna, hyena, foxes, kites etc.).

\section{Vulture locations and occupancy}

Vultures were absent from some expected locations (65 in winter, 55 in summer). However, they were recorded in 923 locations in 2016 in both winter and summer counts. These included 832 winter locations, 91 new summer locations and 120 abandoned winter locations. Seasonal occupancy analysis results are given in Table 2. Naïve estimate or Psi $(\psi)$ values varied minimally in different seasons. However, they varied considerably in different land use-landcover. Probability of occupancy $(\psi)$ was maximum in forest followed by agriculture. Probably 17.6-17.8\% forest was occupied by vultures as compared to just $0.03 \%$ agriculture area. State occupancy was 0.18 to $0.19 \%$. Nevertheless, out of possible 30,825 shelter sites (fishnet sub-cells $=10 \mathrm{~km}^{2}$ ) in the state, vultures occupied only 454 in winter and 408 in summer. Among these sub-cells 230 were common, while 178 and 224 were new in summer and winter, respectively. Similarly, out of 1,409 cells, 312 partial and 1,097 full (fishnet cells, $250 \mathrm{~km}^{2}=$ foraging sites) in the state, they occupied 216 in winter and 200 in summer.

Table 2. Results of occupancy analysis of vultures in Central India

\begin{tabular}{|c|c|c|c|c|c|c|}
\hline \multirow{2}{*}{ Analytical parameter } & \multicolumn{3}{|c|}{ Winter } & \multicolumn{3}{c|}{ Summer } \\
\cline { 2 - 7 } & State & Agriculture & Forest & State & Agriculture & Forest \\
\hline Nä̈ve estimate & 0.1526 & 0.0114 & 0.1105 & 0.1437 & 0.0114 & 0.1252 \\
\hline Psi value & 0.1922 & 0.0378 & 0.1769 & 0.1842 & 0.0378 & 0.1784 \\
(standard error) & $(0.0127)$ & $(0.0194)$ & $(0.0178)$ & $(0.0127)$ & $(0.0194)$ & $(0.0160)$ \\
\hline 95\% confidence & $0.1685-$ & $0.0136-$ & $0.1447-$ & $0.1605-$ & $0.0136-$ & $0.1492-$ \\
interval & 0.2184 & 0.1007 & 0.2144 & 0.2105 & 0.1007 & 0.2118 \\
\hline
\end{tabular}

\section{Richness and abundance}

Figures 1 and 3 depict the vulture count and species distribution. Landcover selection by vultures favored forest (87\%), followed by agricultural landcover (13\%) shown in Figure 3. Seven vulture species were reported: Cinereous Vulture (CV), Egyptian Vulture (EV), Eurasian Griffon (EG), Himalayan Griffon (HG), Long-billed Vulture (LV), Red-headed Vulture (RV) and White-rumped Vulture (WV). The average recorded was 7,028 (6,999 in winter and 7,057 in summer). In decreasing numbers, the species counts were LV (3,351), EV (1,874), WV (1,522), EG (95), RV (93), CV (53) and HG (39). Only HG was not reported during the summer (Table 3). The Slender-billed vulture and Bearded vulture were not found in any count in the study area. 

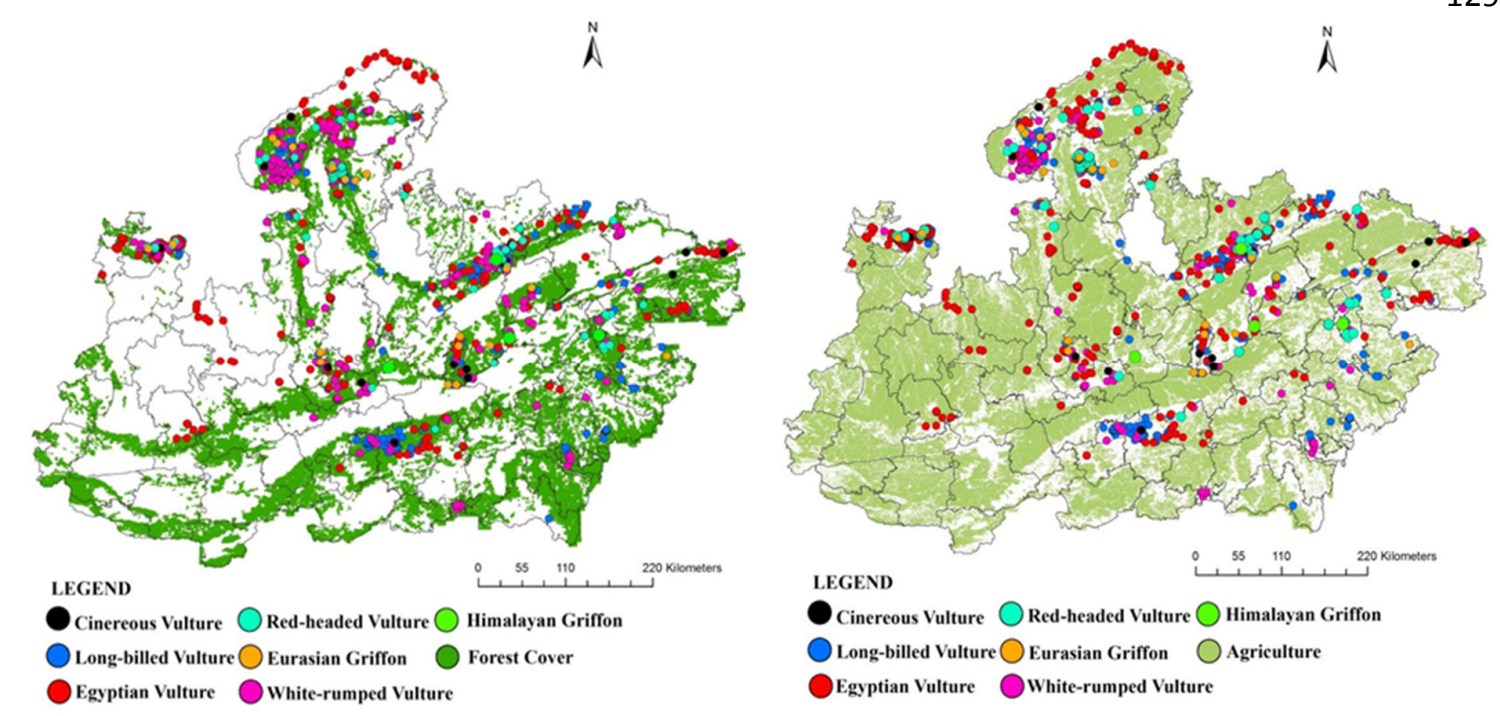

Figure 3. Spatial distribution of vulture species in the study area. Circular spots are the roosting or nesting locations of winter and summer combined. Note that almost all sites (87\%) are in forested area (left), while very few (13\%) in agriculture land use area (right)

Table 3. Population of different vulture species in Central India as per 2016 counts

\begin{tabular}{|c|c|c|c|c|c|c|}
\hline \multirow{2}{*}{$\begin{array}{c}\text { Vulture } \\
\text { species }\end{array}$} & \multicolumn{2}{|c|}{ Summer } & \multicolumn{2}{c|}{ Winter } & \multicolumn{2}{c|}{ Average } \\
\cline { 2 - 7 } & Adult & Juvenile & Adult & Juvenile & Adult & Juvenile \\
\hline Cinereous vulture & 18 & 0 & 85 & 3 & 52 & 2 \\
\hline Egyptian vulture & 1,082 & 179 & 1,894 & 595 & 1,488 & 387 \\
\hline Eurasian Griffon & 42 & 2 & 181 & 6 & 112 & 4 \\
\hline Long-billed vulture & 3,479 & 346 & 2,724 & 152 & 3,102 & 249 \\
\hline Red-headed vulture & 102 & 7 & 76 & 0 & 89 & 4 \\
\hline White-rumped vulture & 1,668 & 132 & 1,146 & 98 & 1,407 & 115 \\
\hline Himalayan Griffon & 0 & 0 & 38 & 1 & 38 & 1 \\
\hline \multirow{2}{*}{ Total } & 6,391 & 666 & 6,144 & 855 & 6,288 & 762 \\
\cline { 2 - 7 } & \multicolumn{3}{|c|}{7,057} \\
\hline
\end{tabular}

\section{Agroclimatic region and ecozone distribution}

Figure 4 shows vulture records in agro-climatic regions and ecozones. For the agro-climatic regions, top records were 1,702 in Vindhyan plateau during winter and 1,391 in Gird region during summer. Among the ecozones, the highest population was in Chambal $(1,463)$ in winter and in Bundelkhand $(1,503)$ in summer. Table 3 shows the vulture counts according to species, depicting the average counts for adults and juveniles, and the counts in summer and winter. For example, out of 7,028 vultures, adults numbered 6,268 and juveniles 760 (6,144 adults and 855 juveniles in winter; 6,391 adults and 666 juveniles in summer). The commonest was LV, which recorded 3,102 adults and 249 juveniles (2,724 adults and 152 juveniles in winter; 3,479 adults and 346 juveniles in summer). The rarest was HG, which recorded 38 adults and 1 juvenile in only winter season. For the ecozones, the average adult and juvenile populations are presented in Figure 4. All the ecozones recorded vultures, in decreasing order: Chambal, Bundelkhand, Malwa, Central, Satpura and Vindhyan. However, only 9 of 11 agro-climatic regions recorded vultures (Bundelkhand, Central Narmada Valley, Chhattisgarh Plain, Gird Region, Kymore Plateau and Satpura Hills, Malwa Plateau, Northern Hill Region of Chhattisgarh, Satpura Plateau and Vindhyan Plateau); the remaining two (Jhabua Hills and Nimar Valley) did not. 


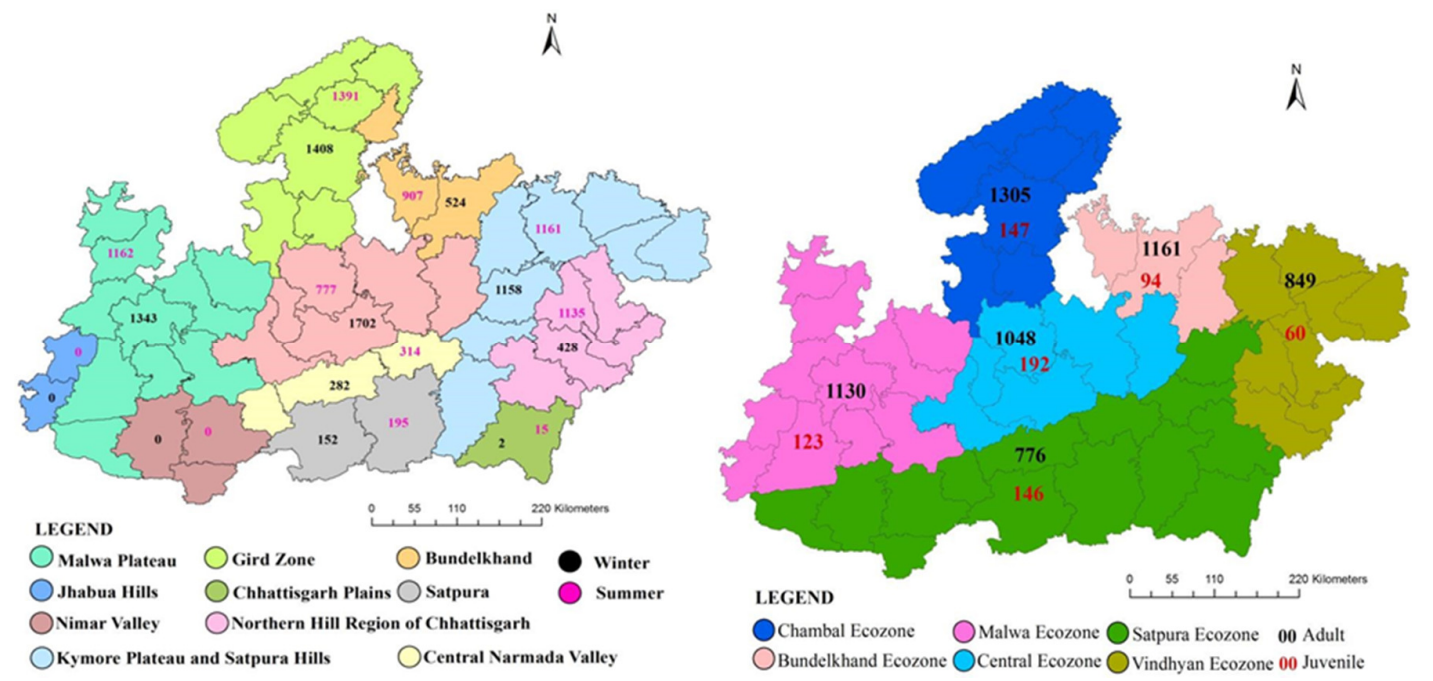

Figure 4. Winter and summer distribution of vultures population in different agro-climatic regions (left) and adults and juveniles spread in different ecozones of the study area. The Eastern side of the state has lower population (wetter areas with moist deciduous and dense forests) than the drier areas with dry deciduous and open forests

The South-Eastern part of the state (subtropical wet and dry climatic region of India) recorded fewer vultures than the Northern part (subtropical climatic region of India). The South-Western part of the state (tropical wet and dry climatic region of India) had almost no vultures, but the North-Western part of the state (semi-arid climatic region) recorded many vultures.

\section{Vulture habitats}

Vulture habitats included woodland (with the most nests), mountain cliffs and agricultural areas. Some EV were recorded in the agriculture areas, while many LV were recorded near mountain cliffs and monuments. Landcover included trees, cliffs, dams, water bodies (drains, riversides, ponds, lakes), old building and monuments, electricity poles and agriculture fields. Most trees species listed in Table 4 were tall $(10-25 \mathrm{~m})$. In terms of percentage roosting use (relative frequency) Boswelia serrata, Ficus religiosa, Terminalia arjuna, Dipterocarpus trubinatus, Madbuca indica, Lannea coromandelica were the most important trees, having composed more than $5 \%$ of total host trees $(n=1,025)$. Species nesting habits are recorded in Table 5. Percentage nesting use (relative frequency) wise (Table 4) Ficus religiosa, Boswelia serrata, Terminalia arjuna, Madhuca indica, Tectona grandis were the most important trees having composed more than $5 \%$ of total host trees $(n=492)$.

\section{Breeding status}

At the 923 vulture locations, several nests were recorded (1,022 in winter, 1,631 in summer). There were 459 active nests ( 318 in winter, 601 in summer), 641 inactive nests ( 544 in winter, 739 in summer) and 225 abandoned nests (160 in winter, 291 in summer). Variants were nests occupied by adults with chicks/juveniles, those with adults without chick/juveniles and unoccupied nests. The locations of these nests are presented in Figure 5. Nest proportions were lower in unprotected area or the forests without specialized management for wild animals. 
Table 4. Different tree species with their relative frequency of hosting the roost and nest of vultures

\begin{tabular}{|c|c|c|c|c|}
\hline SN & Scientific name & Local name & Roost & Nest \\
\hline 1 & Acacia catechu & Khair & 0.5 & 0.4 \\
\hline 2 & Acacia nilotica & Babool & 0.2 & 0.0 \\
\hline 3 & Adina cordifolia & Haldu & 1.0 & 0.6 \\
\hline 4 & Aegle marmelos & $\mathrm{Bel}$ & 0.6 & 0.2 \\
\hline 5 & Albizia lebbeck & Kala siras & 0.0 & 0.2 \\
\hline 6 & Albizia procera & Safed Siris & 0.1 & 0.0 \\
\hline 7 & Anogeisus latifolia & Dhawada & 2.3 & 3.3 \\
\hline 8 & Anogeisus pendula & Kardhai & 0.9 & 1.0 \\
\hline 9 & Anthocephalus kadamba & Kadam & 0.1 & 0.0 \\
\hline 10 & Azadirachta indica & Neem & 1.4 & 1.0 \\
\hline 11 & Bombax ceiba & Semal & 1.5 & 1.0 \\
\hline 12 & Boswelia serrata & Salai & 13.9 & 11.8 \\
\hline 13 & Butea monosperma & Palas & 2.8 & 0.0 \\
\hline 14 & Casearia tomentosa & Chilla & 0.6 & 0.0 \\
\hline 15 & Chloroxylon swietenia & Bhirra & 0.8 & 2.0 \\
\hline 16 & Dalbergia paniculata & Dhobin & 1.4 & 1.8 \\
\hline 17 & Diospyros melanoxylon & Tendu & 3.1 & 2.0 \\
\hline 18 & Dipterocarpus trubinatus & Gurjan & 7.1 & 1.0 \\
\hline 19 & Ficus benghalensis & Banyan & 1.5 & 2.8 \\
\hline 20 & Ficus glomerata & Peepal & 0.0 & 0.6 \\
\hline 21 & Ficus religiosa & Gular & 12.2 & 24.6 \\
\hline 22 & Gmelina arborea & Khamber & 0.1 & 0.0 \\
\hline 23 & Hardwickia binata & Anjan & 0.1 & 0.2 \\
\hline 24 & Holoptelia integrifolia & Chirhul & 1.1 & 0.2 \\
\hline 25 & Lagerstromia parviflora & Laidia & 0.2 & 0.0 \\
\hline 26 & Lannea coromandelica & Gunja & 5.4 & 1.0 \\
\hline 27 & Madhuca indica & Mahua & 5.8 & 5.9 \\
\hline 28 & Mallotus philippinensis & Rohini & 0.1 & 0.0 \\
\hline 29 & Mangifera indica & Mango & 0.8 & 1.8 \\
\hline 30 & Miliusa tomentosa & Kari & 0.7 & 0.0 \\
\hline 31 & Mytragyna parviflora & Kaim & 2.5 & 4.5 \\
\hline 32 & Pometia pinnata & Kasai & 0.2 & 0.0 \\
\hline 33 & Prosopis juliflora & Prosopis & 0.4 & 0.0 \\
\hline 34 & Pterocarpus marsupium & Bija & 0.1 & 0.0 \\
\hline 35 & Schleichera oleosa & Kusum & 0.1 & 0.2 \\
\hline 36 & Shorea robusta & Sal & 4.9 & 2.4 \\
\hline 37 & Sterculia urens & Kullu & 1.4 & 0.0 \\
\hline 38 & Sygygium cuminii & Jamun & 0.4 & 0.0 \\
\hline 39 & Tamarindus indica & Tamarind & 1.1 & 1.2 \\
\hline 40 & Tectona grandis & Sagaun & 4.2 & 5.9 \\
\hline 41 & Terminalia arjuna & Arjun & 8.0 & 10.6 \\
\hline 42 & Terminalia belerica & Babeda & 4.1 & 3.5 \\
\hline 43 & Terminalia chebula & Harra & 0.1 & 0.0 \\
\hline 44 & Terminalia tomentosa & Saaj & 4.5 & 7.1 \\
\hline
\end{tabular}


Jha KK et al. (2020). Not Sci Biol 12(1):124-142.

132

\begin{tabular}{|c|c|c|c|c|}
\hline 45 & Wrightia tinctoria & Doodhi & 0.2 & 0.4 \\
\hline 46 & Not identified & & 2.0 & 0.6 \\
\hline
\end{tabular}

Table 5. Resident vultures' nesting habits in central India

\begin{tabular}{|c|c|c|}
\hline Vulture species & Trees & Other sites \\
\hline Egyptian & $\begin{array}{c}\text { Arjun, Dhawda, Kardhai, Peepal, Baheda, Banyan, Gurjan, } \\
\text { Mahua, Aam, Neem, Gular, Saja, Sagaun }\end{array}$ & $\begin{array}{c}\text { Cliffs, monuments, } \\
\text { electric poles }\end{array}$ \\
\hline Long-billed & $\begin{array}{c}\text { Arjun, Baheda, Banyan, Saja, Kaim, Mahua, Aam, Neem, } \\
\text { Peepal, Gular, Sagaun, Dhobin, Sal, Semal, Ghiriya, Tendu, } \\
\text { Dhawda }\end{array}$ & Cliffs, monuments \\
\hline Red-headed & $\begin{array}{c}\text { Dhawda, Dhobin, Gurjan, Kaim, Mahua, Peepal, Sal, } \\
\text { Sagaun, Ghiriya, Mahua and Tendu }\end{array}$ & None recorded \\
\hline White-rumped & $\begin{array}{c}\text { Arjun, Anjan, Dhawda, Baheda, Banyan, Bel, Peepal, } \\
\text { Gurjan, Kaim, Kardhai, Mahua, Aam, Neem, Sal, Sagaun, } \\
\text { Ghiriya, Tamarind and Tendu }\end{array}$ & Cliffs \\
\hline
\end{tabular}

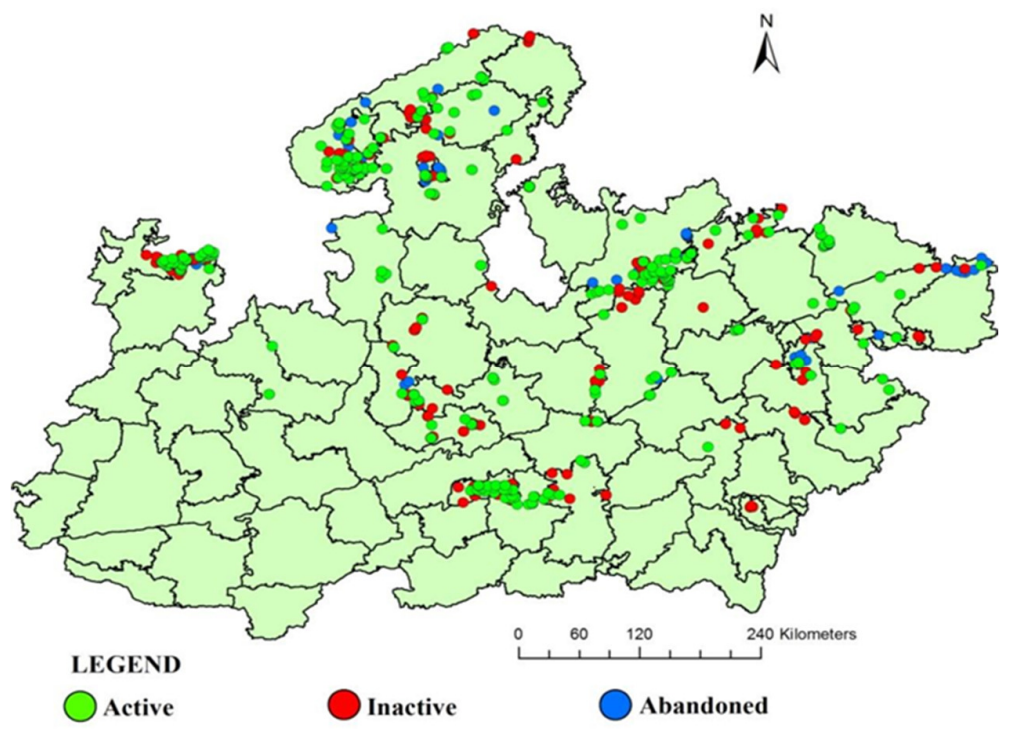

Figure 5. Spatial distributions of different categories of vulture nests found in Central India. Active nests (please note larger clusters of green circles) are mostly concentrated in Wildlife Protected Area

\section{Discussion}

Vultures are very cautious creatures, sensitive to disturbance and reluctant to alight near a carcass if there is too much noise or disturbance (Mundy et al., 1992). During diclofenac use, while not denying the death or decline in population from millions, it was possible that the vultures avoided farms as they perceived a poisoning threat. This also takes the clue from the respondents $(n=57)$ as just four percent of them saw the dead bodies of vultures in their surroundings (Pers. Comm. one case of train accident killing several WV, Amita Kanaujia, a conservation biologist and another case of heat stroke to LV near forest area, Ajit Dixit, a veterinary surgeon). Further, the protected forests especially the national parks, wildlife sanctuaries and tiger reserves have sufficient ungulate population in MP and they are the diclofenac-safe habitat. Prakash et al. (2012) speculated that the slowdown (indirect enhancement in population) might be due to the remaining vultures confining themselves to areas where much of the birds' food comprised uncontaminated carcasses of 
wild ungulates. Jha (2015a) also reported very high concentrations of all the vultures except EV, in protected wildlife areas (national park and sanctuaries) as compared to neighboring forests and agriculture area.

Forests recorded higher vulture presence ( $87 \%$ in the $28 \%$ of the state under forest) than agricultural landcover ( $13 \%$ in the $52 \%$ of state under agricultural landcover). The highest and lowest records (in the Chambal ecozone and Vindhyan ecozone, respectively) may correlate with ecozone parameters (rainfall, temperature, orography, forest canopy covers etc.; see Table 1) as suggested by others. For example, rainfall (Virani et al., 2012), high temperature (Chaudhry, 2007; Simmons and Jenkins, 2007), high-density cover and orography are important for vulture presence and breeding (Campbell, 2015). It can be speculated that agroclimatic regions are less significant than Ecozones as regards the vulture habitation.

\section{Population factors}

As recorded in MP, resident (LV, WV, RV and EV) and migratory (EG, HG and CV) vulture species were also reported in other parts of the country such as Rajasthan (Saran and Purohit, 2012; Purohit and Saran, 2013), Uttar Pradesh (Jha, 2015a), Gujrat (Kamboj et al., 2016), Himachal Pradesh (Thakur and Narang, 2012), Karnataka (Subramanya and Naveein, 2006), Tamil Nadu (Ramakrishnan et al., 2014), etc. Himalayan Griffon, EG, CV and RV have very low contribution (3-4\%) in the total vulture population (6999-7057 individuals) of the study area. Other vultures like, EV, LV and WV have major contribution, for example, $18-36 \%, 41-54 \%$ and $18-26 \%$, respectively. Among the low contributors to the population, all others except RV are practically nonresident (migrant or visitor). All the major contributors are resident vultures in MP and reported to breed satisfactorily (Naoroji, 2006).

Juvenile percentage is an indicator of population recruitment and annual breeding success (Campbell, 2015). Adult and juvenile proportions (juveniles per hundred adults: jpha) or fresh recruitment (juvenile percentage in total population: jptp) may be used as indicators of population growth. Juvenile proportions and fresh recruitment in the present study averaged 12 jpha and 11 jptp, respectively, for all vultures in the state. This is encouraging in the light of previous prediction. However, such parameters are highly variable (3$26 \%$ and 3-21\%, respectively). Among the resident and breeding vultures in MP, jptp indicated varied success of breeding in following order: $\mathrm{EV}(21 \%)>\mathrm{WV}(8 \%)>\mathrm{LV}(7 \%)$ and RV (4\%). Average juvenile percentage in the population (10\%) seems to be a satisfactory growth indicator. Although EV showed high juvenile percentages, juvenile increase in $\mathrm{WV}$ and $\mathrm{LV}$ is like annual population increase (7\%) of vultures (LV, WV, RV, EV, EG, HG and CV) in arid regions (Khatri, 2013).

Nest-occupancy in the current research, recorded a 10-17\% breeding population, $17-21 \%$ potential breeding population and non-breeders (62-74\%, under-aged or over-aged vultures). Bird species commonly record adult non-breeders, partly due to sparse nesting areas (Campbell, 2015). Forests offered superior food and nesting sources than agricultural landcover, hence there were more vulture records in forest (87\%) than agricultural landcover (13\%). Possibly, there were fewer uninfected carcasses and undisturbed trees and cliffs in agricultural land. Tall forest trees $(>10 \mathrm{~m})$ and elevated ledges/caves/crevices $(\leq 25 \mathrm{~m})$ offered refuge from predators, and foraging platforms (Chhangani, 2003; Chomba and M'Simuko, 2013; Campbell, 2015). Smaller trees in agricultural landcover were utilized when tall trees were absent. This is in agreement with earlier reports of Kambale (2011) and Harris (2013).

Diclofenac use (Campbell, 2015) precluded its rapid withdrawal from the vulture food supply. The three Gyps species were almost extirpated (Campbell, 2015). Prakash et al. (2007) suggested that only one in 1000 Gyps benghalensis (99.9\%) and three in 1000 Gyps indicus and Gyps tenuirostris (96.8\%) survived. However, current species counts of Gyps benghalensis (1522) and Gyps indicus (3350) in MP may indicate a one thousand-fold decline over a decade is exaggerated. The population trend in MP is lacking, hence many experts are skeptical (Pers. comm. Jitendra Agrawal CWLW, MP). Data is scanty on the threshold level population for the extinction of resident vultures and diclofenac ban impact (Taggart et al., 2007). Likely, diclofenac caused extinctions (Green et al., 2004; Oaks et al., 2004; Shultz et al., 2004; Prakash et al., 2012), 
134

reported recoveries also appear exaggerated. Diclofenac abolition is uncertain (Taggart et al., 2007); users cite availability and high potency over other NSAIDs (Saini et al., 2012; Dama, 2014; Cuthbert et al., 2016, for India, Phuyal et al., 2016, for Nepal). As vultures are slow breeders (Campbell, 2015), the annual decrease in population in the state of UP was 3.2\% (Jha, 2015a). The maximum population increase in a year could only be 2.5-3.45\% (Changani and Mohnot, 2008). These figures may not be comprehensive, requiring further research. The two hypotheses, of extinction risk (Prakash et al., 2007) and reduced population decline (Prakash et al., 2012) may be based on untested or hypothetical models (Pavokivic and Susic, 2005).

Records of past vulture numbers is scanty or subjective (Thakur and Kataria, 2012; Thakur and Narang, 2012, etc.). Statements include 'several tens of millions of individuals' of Gyps bengalensis (Houston 1985 in Botha et al., 2017). Baral et al. (2013), the only quantitative report, gives the WV population as 15000. More recently, Botha et al. (2017) gave global population of EV, RV, WV, and LV as 18000-57000, 3500-15000, 8000 and 12000, respectively. Therefore, for MP this corresponds to 3.3\%, 0.6\%, 19\% and $27.9 \%$ of the global population. However, the Jptp of the combined population ranged between $6.5 \%-15.7 \%$ in different ecozones of MP. Vindhyan, Bundelkhand and Malwa require special care for conservation since they have a jptp of less than 10\%. The lack of uninfected food and drought, malaria, storms, and habitat degradation exacerbate the diclofenac problem (Ramakrishnan et al., 2014; Jha, 2015a; Paital, 2016).

Our findings dispute some media statements. For example, LV in MP constitute $28 \%$ of global population, but Saxena (2017) argued that MP has $40 \%$ of the global LV population. This quoted an expert, who doubted its veracity (Pers. Comm. Chris Bowden, a vulture expert). Another report citing 'vulture population increase in Charotar region (Anand district) of Gujarat in 2016 (Ruperal, 2016) may exaggerate local changes. Kamboj et al. (2016) reported Gyps populations decreased in the whole state as well as in central Gujarat, to which Anand and other districts belongs. The increase in Charotar could be only local, as in our study and that of Naoroji (2006).

\section{Habitats and sites}

Vulture presence decreased with forest density. Eurasian and African vultures have no sense of smell for carrion detection; hence their avoidance of closed canopies (Brown, 1985; Schulz, 2007; Campbell, 2015; Samson et al., 2016). Roosting and nesting occurred on trees and cliffs, while water bodies were used for drinking. Other studies record use of similar tree species in other regions. These include Tectona grandis, Bombax ceiba, Terminalia tomentosa, Dalbergia sissoo in Uttarakhand (Das et al., 2011); Terminalia arjuna, Terminalia bellerica, Alstonia scholaris, Mangifera indica in Maharashtra (Pande et al., 2013); Ficus benghalensis, Ficus religiosa, in erstwhile East Bengal now Bangladesh (Khan, 2013) and in Tamil Nadu (Ramakrishnan et al., 2014). Out of 44 tree species used by vultures for roosting, 14 (mostly shorter) trees were not used for nesting, indicating a preference for taller trees. Vulture species not included in the current study, including Eurasian Black vultures, Lappet-faced vulture (Torgos tracheliotus), White-headed vulture (Trigonoceposc cipitalis) and White-backed vulture (Gyps africanus), are also tree nesters (Campbell, 2015).

Large trees (Chhangani, 2007; Dhakal et al., 2014) provided predator avoidance, suitable microclimates (Campbell, 2015) and increased mobility (Wright et al., 1986) for vultures. Nest elevation included those of the White-backed (-rumped) vulture at $16.6 \mathrm{~m}$ (Chomba and M'Simuko, 2013), $8 \mathrm{~m}-28$ $\mathrm{m}$ (Subedi and DeCandido, 2014), $14.8 \mathrm{~m}$ (Thakur and Narang, 2012), 18 to $36 \mathrm{~m}$ (Naoroji, 2006), above 21 $\mathrm{m}$ (Thompson et al., 1990) and 25-30 m (Ramkrishnan et al., 2014). Other species were recorded in smaller trees (Mangifera indica, Acacia nilotica, Azadirachta indica, Prosopis cineraria) in other regions such as arid Rajasthan and Maharashtra (Chhangani, 2007; Kambale, 2011; Khatri, 2013).

High cliff nesting averaged $25 \mathrm{~m}$ to $35 \mathrm{~m}$ elevation, generally inaccessible to humans from ground level or cliff top (Subramanya and Naveein, 2006). Cliff locations provided predator visibility, easier nest access and reduced human disturbances (Donazar et al., 1993; Yamac, 2007). Some species favored cliffs (e.g. EV 
and LV) and others favored trees (e.g. KV and WV), but there were also inter-species reversals (trees to cliffs and vice versa) in the current study and others (Navaneethan et al., 2015). For example, while Ramesh et al. (2011) reported LV nesting on Dalbergia lanceolaria tree, Venkitachalam and Senthilnathan (2015) recorded LV nesting on rock cliffs. KV and LV were also observed roosting on Albizzia procera and Shorea robusta trees and EV Butea monosperma trees. Some vulture species, their habitats and companion scavengers in the study area are presented in Figures 6-13.

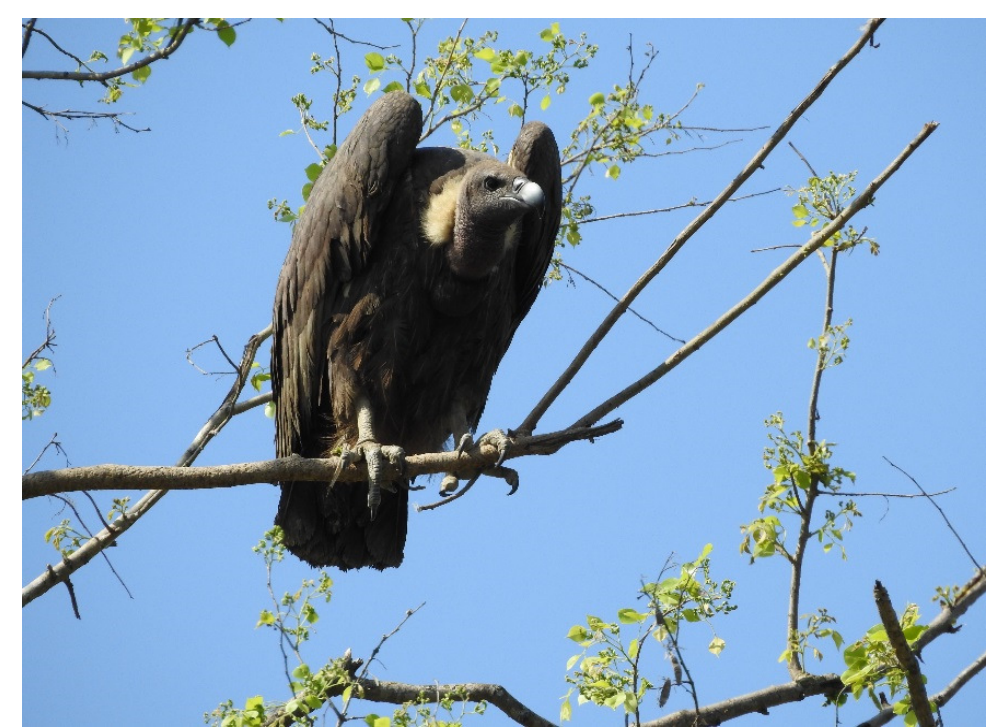

Figure 6. Tree nesting, critically endangered, resident White-rumped vulture Gyps bengalensis perched on a Sheesham tree, Dalbergia sissoo

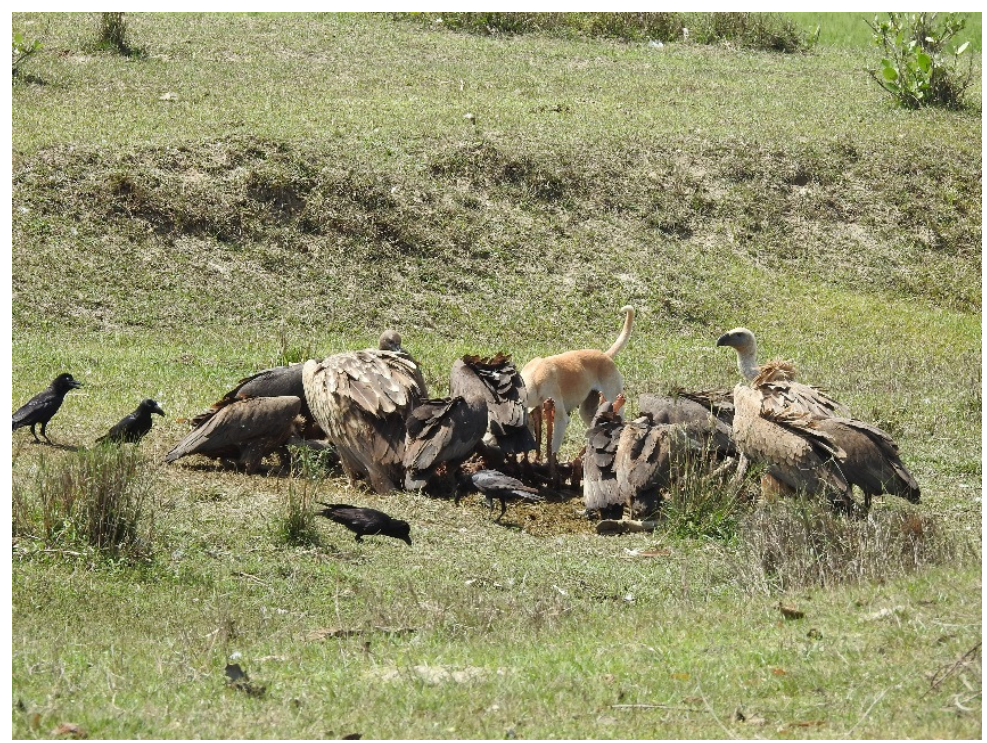

Figure 7. A wake of vultures (Himalayan Griffon and White-rumped Vultures) feeding on cattle carcass. Companion scavengers like, dog and crows can also be seen competing for the carrion 


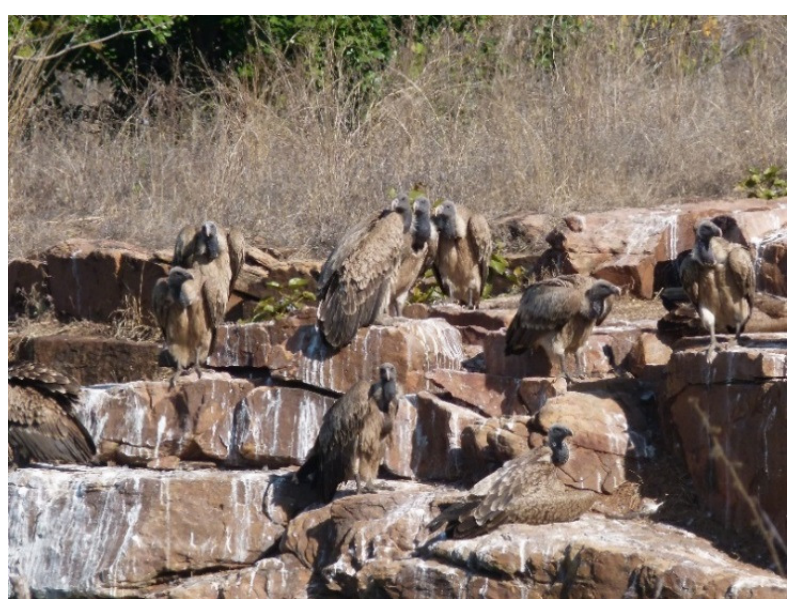

Figure 8. A group of cliff nesting, Critically Endangered, resident Indian or Long-billed Vulture Gyps indicus resting on ledges near permanent roosting location

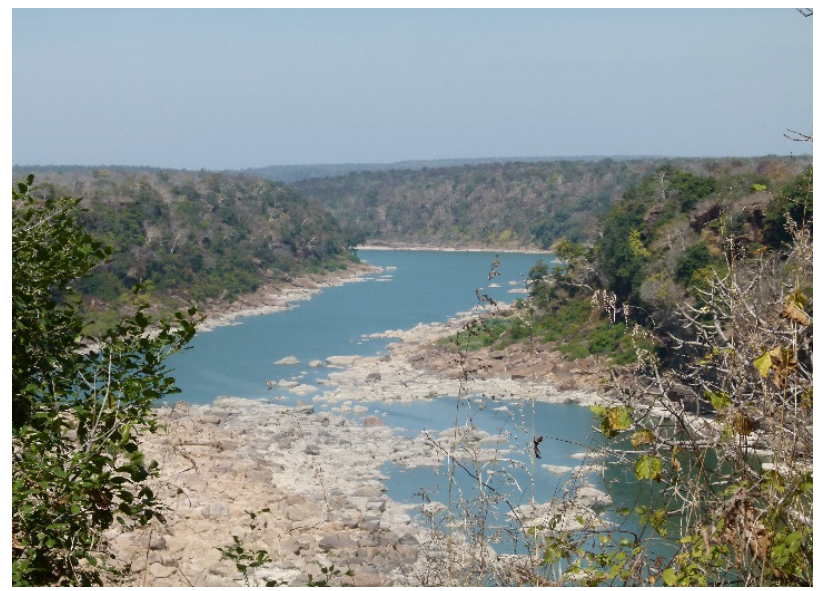

Figure 9. An ideal landscape for cliff nesting vultures. A Dry Deciduous Tropical Forest on plateau (cliff providing nesting ledges and crevices) cut by a meandering river (perennial water source)

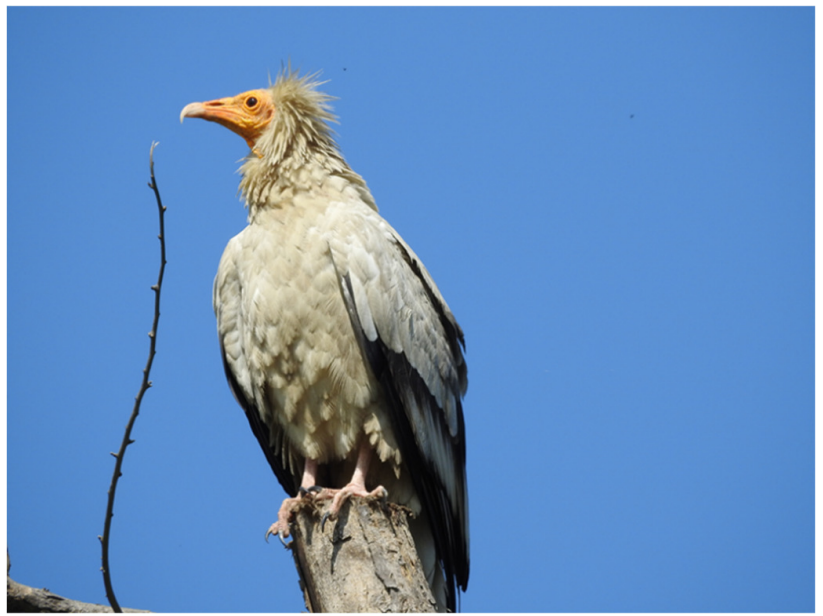

Figure 10. A cliff nesting, Endangered, resident, Egyptian Vulture Neophron percnopterous perched on a hacked drying tree 


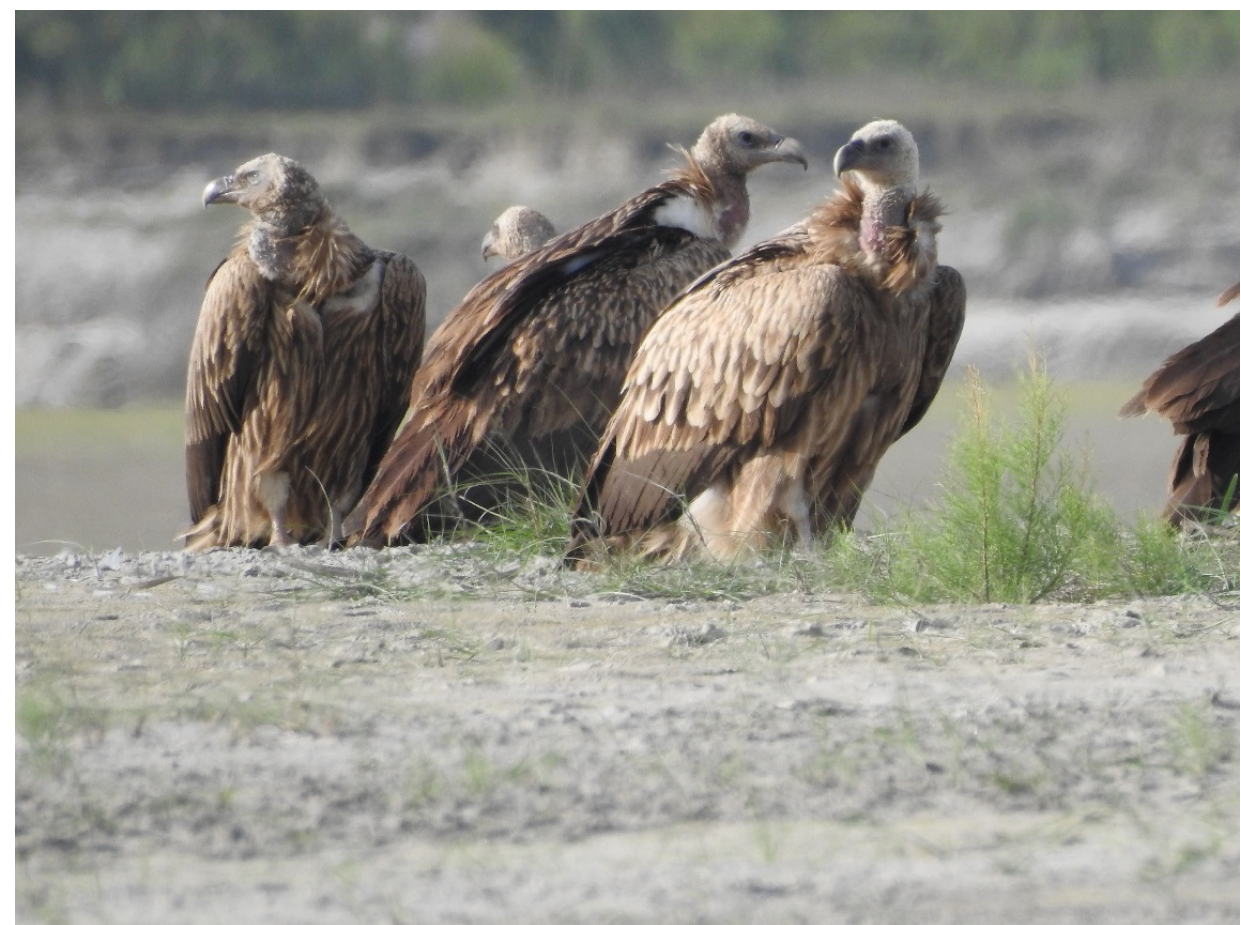

Figure 11. A small group of vultures on mud flat of a river basking late afternoon sun. Himalayan Griffon Gyps himalayensis vulture is a Near Threatened and migratory

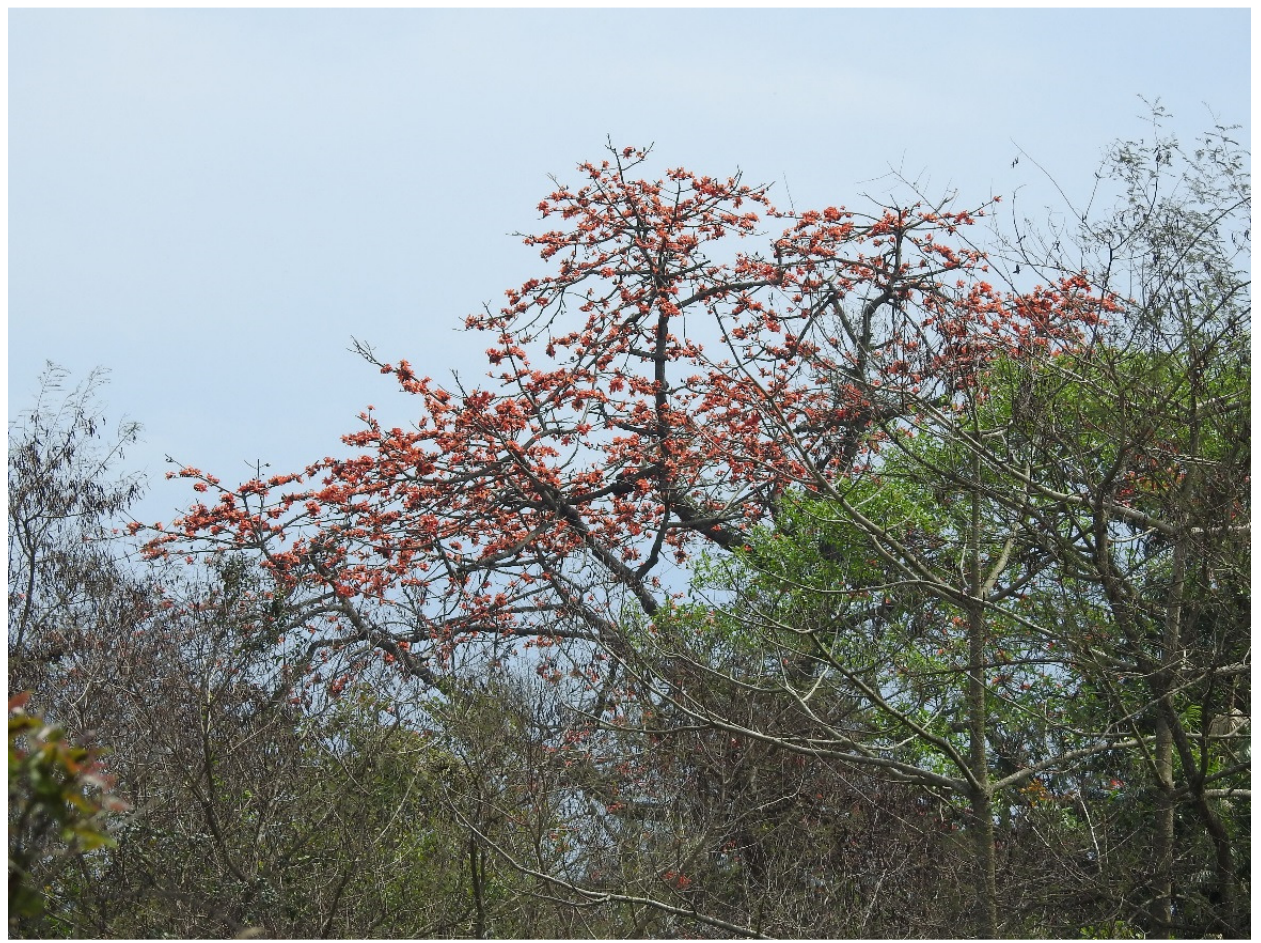

Figure 12. Treescape of a moist deciduous tropical forest having a silk cotton tree Bombax ceiba with red flowers. This is very common and one of the most favoured trees for nesting, generally by White-rumped vulture 


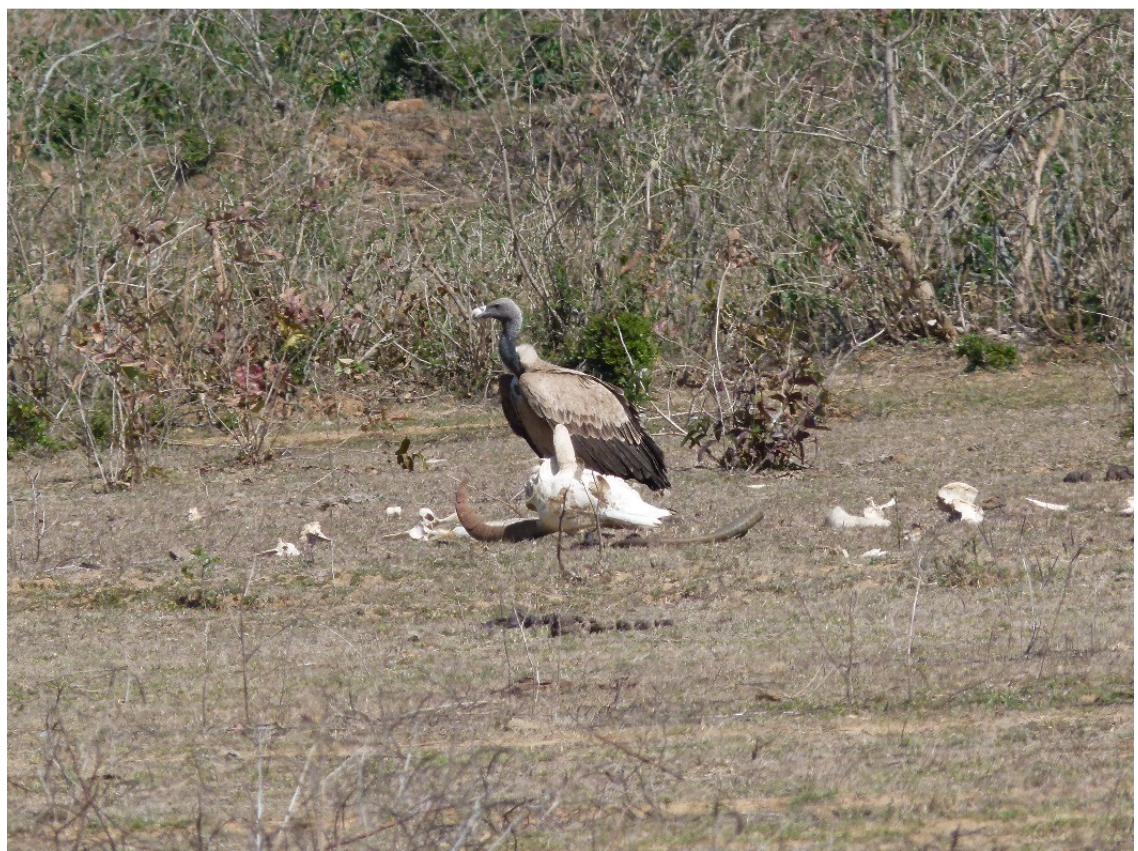

Figure 13. Long-billed or Indian Vulture Gyps indicus revisits a foraging area while roaming in a barren field in search of food. An old cattle carcass skull can be seen in the foreground

\section{Local movements}

Vulture summer ranges varied from winter ranges, either towards denser, protected forest or varied landcover. This search for optimal feeding, nesting and roosting habitat is found among vultures and other species (Saran and Purohit, 2013). In the study area, movements responded to water and food availability, and temperature and humidity variability, as noted in other studies (Campbell, 2015; Saran, 2017). Naoroji (2006) and Bildstein (2006) record the LV, WV and CV as irruptive and locally migratory. For example, other studies record similar results for the Cinereous vulture in other continents, with seasonal changes in home ranges, and sometimes overlaps in the home ranges during the breeding and non-breeding periods (Campbell, 2015).

\section{Competing scavengers}

Several competing scavengers were seen on the carcass at a time but feral dogs dominated scavenging, possibly due to declining vulture populations as also recorded by Markandya et al. (2008). Other competitors in the study area included the common raven (Corvus corax), house crow (Corvus splendens), cattle egret (Bubulcus ibis), drongo (Dicrurus macrocercus), jackal (Canis aureas) and wild pig (Sus scrofa). They were reported in the same region by Navaneethan et al. (2015). These concur with findings in other regions of India (Purohit and Saran, 2013; Chhangani and Mohnot, 2008; Jha, 2015a). Moleon et al. (2015) hypothesized that larger carcasses attracted more species and scavenger numbers, was observed in the current study as well.

\section{Conservation policy}

The findings of the current study make important contributions to the literature on conservation policy and management action (Jha, 2015a). Important points concern vulture dependence on forested areas, the low relevance of agricultural land use (except for Egyptian vultures), high usage of open landcover is favored for roosting and nesting, and preferences cliffs and large trees for roosting and nesting. These indicate that ecological knowledge is vital for endangered species and orography and forest structure influence vulture 
presence as also reported by Sutherland and Green (2004) and Campbell (2015). Human disturbance was insignificant for vulture presence, is contrary to the findings of Bamford et al. (2009) and Chomba and M'Simuko (2013). Recovery from the diclofenac event was evident. Like others, our findings support nest protection (Pande et al., 2013), tree protection (those used for nesting and roosting, and cattle) (Poirazidis et al., 2004; Chhangani, 2007; Yamac, 2007; Forest Survey of India, 2011), ungulate protection, diclofenac bans (Hla et al., 2010), restriction of human activities in breeding months (Jha, 2015a) and minimum buffers of $500 \mathrm{~m}$ (Margalida et al., 2011) between nests and disturbance source (Chomba and M'Simuko, 2013).

The large trees of preferred species for roosting and nesting in the forest, even though commercially important, must be excluded from felling so that the current and future sites remain intact. Inclusion of such provisions in forest management plans will minimize the conflict between forest exploitation and vulture conservation (Poirazidis et al., 2004; Yamac et al., 2006). Also, branch lopping of trees as suggested by Chhangani (2007) must be banned.

Finally, prey abundance, a key factor for vulture presence (Kendall et al., 2014) may be supported by traditional pastoralism, especially the relationship between vultures and migrating livestock populations as suggested by Mateo-Tomas and Olea (2009) in Malwa and Chambal ecozones with minimal wild ungulate populations.

\section{Conclusions}

The present study provided for the first-time count data of different species of vultures, which could be used for future monitoring and conservation strategies. Further studies may apply the present hypotheses to other regions. For example, (i) Vultures rely heavily on forested area and agriculture does not have much impact except in the case of Egyptian vultures, (ii) Comparatively drier area with open canopy are more suitable as roosting and nesting habitat, (iii) Interspecies differences in nesting choices (cliff or trees) and (iv) Human presence do not affect vulture colonizing in forest. The current findings provide sufficient support for enhanced conservation actions for vultures: (i) The nests identified so far (active or inactive or abandoned) must be safeguarded for current and future breeding of population. Branch lopping of trees must be banned, (ii) Large trees of preferred species for roosting and nesting must be excluded from felling, so that the sites remain intact. Inclusion of such provisions in forest management plans will minimize the conflict between forest exploitation and vulture conservation (Poirazidis et al., 2004; Yamac et al., 2006), and (iii) Prey abundance and their mortality should be ensured through traditional pastoralism or migrating livestock populations in areas with low ungulate populations.

\section{Acknowledgements}

Authors are thankful to MP Forest Department and State Biodiversity Board for financial support to Vulture Atlas Project.

\section{Conflict of Interests}

The authors declare that there are no conflicts of interest related to this article. 


\section{References}

AR MPSBB (Annual Report Madhya Pradesh State Biodiversity Board) 2007-2008.

Bamford AJ, Monadjem A, Hardy ICW (2009). Nesting habitat preference of the African white-backed vulture Gyps africanus and the effects of anthropogenic disturbance. Ibis 151:51-62.

Bhusal KP (2011). Population status and breeding success of Himalayan griffon, Egyptian vulture and Lammergeier in Gherabhir, Arghakhanchi, Nepal, Unpublished Master Thesis. Tribhuvan University Kirtipur, Kathmandu.

Bildstein KL (2006). Migrating raptors of the world: their ecology and conservation. Ithaca, Cornell University Press.

Bonal BS, Prakash V (2014). Ex situ and in situ efforts in saving three critically endangered resident Gyps species of vultures (white-backed vulture, Gyps bengalensis, long-billed vulture Gyps indicus, and slender-billed vulture, Gyps tenuirostris) from possible extinction in India. CBSG Annual Meeting - Plenary Abstract.

Botha AJ, Andevski J, Bowden CGR, Gudka M, Safford RJ, Tavares J, Williams NP (2017). Multi-species action plan to conserve African-Eurasian vultures. CMS Raptors MOU Technical Publication No. 4. CMS Technical Series No. 33. Coordinating Unit of the CMS Raptors MOU, Abu Dhabi.

Bowden C (2012). Vulture population trends and current status in the wild - a global and regional perspective. Symposium on Developing a Regional Response to the Conservation of South Asia's Critically Endangered Vulture Species, 3rd - 4th May 2012, New Delhi.

Campbell M (2015). Vultures: their evolution, ecology and conservation. London and New York, CRC Press, Taylor and Francis Group.

Campbell M (2017). The conservation biology of vultures. In: Campbell M (Ed). Biological Conservation in the 21st Century. New York, NY, Nova Science Publishers.

Chaudhry MJI (2007). Are cape vultures (Gyps coprotheres) feeling the heat? Behavioural differences at north and south facing colonies in South Africa. Cape Town, University of Cape Town.

Chhangani AK (2003). Predation on vultures, their eggs and chicks by different predators in and around Jodhpur. Newsletter for Birdwatchers 43(3):38-39.

Chhangani AK (2007). Sightings and nesting sites of red-headed vulture Sarcogyps calvus in Rajasthan, India. Indian Birds 3(6):218-221.

Chhangani AK, Mohnot SM (2008). Demography of migratory vultures in and around Jodhpur, India. Vulture News 58:23-34.

Chomba C, M'Simuko E (2013). Nesting patterns of raptors: white backed vulture (Gyps africanus) and African fish eagle (Haliaeetus vocifer), in Lochinvar National Park on the Kafue flats, Zambia. Open Journal of Ecology 3(5):325-330.

Cuthbert RJ, Prakash V, Saini M, Upreti S, Swarup D, Das A, ... Taggart M (2011). Are conservation actions reducing the threat to India vulture populations? Current Science 101(11):1480-1484.

Cuthbert RJ, Taggart MA, Saini M, Sharma A, Das A, Kulkarni MD, ... Green RE (2016). Continuing mortality of vultures in India associated with illegal veterinary use of diclofenac and a potential threat from nimesulide. Oryx 50(1):104-112.

Dama M (2014). The diclofenac ban is helping vultures conservation; what further pharmaceutical threats loom ahead? Current Science 107(4):564-565.

Das SK, Dashahare A, Marathe S, Kundu N, Kesharwani R (2011). Status of raptors with special reference to vultures in and around Rajaji National Park, India. World Journal of Zoology 6(4):350-356.

Dhakal H, Baral KM, Bhusal KP, Sharma HP (2014). First record of nests and breeding success of red-headed vulture Sarcogyps calvus and implementation of vulture conservation programs in Nepal. Ela Journal 3(3):9-15.

Donazar JA, Hiraldo F, Bustmante J (1993). Factors influencing nest-site selection, breeding density and breeding success in the bearded vulture (Gypeatus barbatus). Journal of Applied Ecology 30:504-514.

Forest Survey of India (2011). Atlas forest types of India. Forest Survey of India, Dehradun.

Gilbert M, Watson RT, Virani MZ, Oaks LJ, Ahmed S, Chaudhry MJI, ... Khan AA (2006). Rapid population declines and mortality clusters in three Oriental White-backed vulture Gyps bengalensis colonies in Pakistan due to diclofenac poisoning. Oryx 40(4):388-399.

Harris RJ (2013). The conservation of Accipitridae vultures of Nepal: a review. Journal of Threatened Taxa 5(2):36033619. 
Hla H, Shwe NM, Htun TW, Zaw SM, Mahood S, Eames JC, Pilgrim JD (2010). Historical and current status of vultures in Myanmar. Bird Conservation International 21(4):376-387.

Jha KK (2015a). Distribution of vultures in Uttar Pradesh, India. Journal of Threatened Taxa 7(1):6750-6763.

Jha KK (2015b). Madya Pradesh Mein Giddh: Pahchan Pustika. [Vultures in Madhya Pradesh: An identification booklet]. Bhopal: Indian Institute of Forest Management.

Jha KK (2018). Mapping and management of vultures in Indian stronghold. In: Campbell MO (Ed). Geomatics and conservation biology. NOVA Science Publisher, New York pp 45-76.

Joshi MK, Chalise MK, Chaudhary A, Katuwal HB (2015). Himalayan vultures in Khodpe far west Nepal: Is there any threat? Journal of Threatened Taxa 7(14):8128-8133.

Kambale AA (2011). A study on breeding behaviour of oriental white-backed vulture (Gyps bengalensis) in Anjarle and Deobag, Maharashtra. Dehradun, Wildlife Institute of India.

Kamboj RD, Tatu K, Munjpara SB (2016). Status of vultures in Gujrat - 2016. Gandhinagar, Gujrat Ecological Education and Research (GEER) Foundation.

Kendall CJ, Virani MZ, Hopcraft JGC, Bildstein KL, Rubenstein DI (2013). African vultures don't follow migratory herds: scavenger habitat use is not mediated by prey abundance. PLoS ONE 9(1):e83470.

Khan MMH (2013). Population, breeding and threats to the white-rumped vulture Gyps bengalensis in Bangladesh. Forktail 29:52-56.

Khatri PC (2013). Home range use of winter migratory vultures in and around Jorbeer, Bikaner (Rajasthan) India. Bioscience Discovery 4(1):96-99.

Margalida A, Moreno-Opo R, Arroyo BE, Arredondo A (2011). Reconciling the conservation of endangered species with economically important anthropogenic activities: interaction between cork exploitation and the cinereous vulture in Spain. Animal Conservation 14:167-174.

Mateo-Tomas P, Olea PP (2009). Combining scales in habitat models to improve conservation planning in an endangered vulture. Acta Oecologica 35:489-498.

Moleon M, Sanchez-Zapata JA, Margalida A, Carrete M, Owen-Smith N, Donazar JA (2014). Humans and scavengers: evolution of interactions and ecosystem services. BioScience 64:394-403.

Moleon M, Sanchez-Zapata JA, Sebastian-Gonzalez E, Owen-Smith N (2015). Carcass size shapes the structure and functioning of an African scavenging assemblage. Oikos 124:1391-1403.

Mundy PJ, Butchart D, Ledger JA, Piper SE (1992). The vultures of Africa. Acorn Books \& Russel Friedman Books, Randburg and Halfway House.

Naoroji R (2006). Birds of prey of the Indian subcontinent. Om Books International, NOIDA.

Navaneethan B, Sankar K, Qureshi Q, Manjrekar M (2015). The status of vultures in Bandhavgarh Tiger Reserve, Madhya Pradesh, Central India. Journal of Threatened Taxa 7(14):8134-8138.

Ogada DL, Keesing F, Virani MZ (2011). Dropping dead: causes and consequences of vulture population declines worldwide. Annals of The New York Academy of Sciences 1249(1):57-71.

Pande S, Mestri P, Deshpande P, Warange A, Mahabal A (2013). Promising trend of in situ breeding of Oriental whiterumped vulture Gyps bengalensis in Raigad District, Maharashtra, India: conservation implications for reintroduction of ex situ populations. Journal of Threatened Taxa 5(7):4106-4109.

Phuyal S, Ghimire HR, Shah KB, Bara HS (2016). Vultures and people: local perceptions of a flow-density vulture population in the eastern mid-hills of Nepal. Journal of Threatened Taxa 8(14):9597-9609.

Poirazidis K, Goutner V, Skartsi T, Stamou G (2004). Modelling nesting habitat as a conservation tool for the Eurasian black vulture (Aegypius monachus) in Dadia Nature Reserve, northeastern Greece. Biological Conservation 118:235-248.

Prakash V, Green R, Pain DJ, Ranade SP, Saravanan S, Prakash N, ... Cunningham AA (2007). Recent changes in populations of resident Gyps vultures in India. Journal of the Bombay Natural History Society 104 (2):129-135.

Prakash V, Bishwakarma MC, Chaudhary A, Cuthbert R, Dave R, Kulkarni M, ... Green RE (2012). The population decline of Gyps vultures in India and Nepal has slowed since veterinary use of diclofenac was banned. PLoS One $7(11)$.

Ramakrishnan B, Kannan G, Samson A, Ramkumar K, Ramasubramanian S (2014). Nesting of white-rumped vulture (Gyps Bengalensis) in the Segur Plateau of the Nilgiri North forest Division, Tamilnadu, India. Indian Forester 140(10):1014-1018. 
142

Ramesh T, Sankar K, Qureshi Q (2011). Status of vultures in Mudumalai Tiger Reserve, Western Ghats, India. Forktail 27:96-97.

Ruperal P (2016). Vulture population on rise in Charotar. Times of India. http://timesofindia.indiatimes.com/city/vdodara/vulturepopulationonriseincharotar/articleshow/5 1725294.cms.

Saini M, Taggart MA, Knopp D, Upreti S, Swarup D, Das A, ... Cuthbert RJ (2012). Detecting diclofenac in livestock carcasses in India with an ELISA: A tool to prevent widespread vulture poisoning. Environmental Pollution 160:1116.

Saran R (2017). Population monitoring and annual population fluctuation of migratory and resident species of vultures in and around Jodhpur, Rajasthan. Journal of Asia-Pacific Biodiversity 10:342-348.

Saran R, Purohit A (2013). Vulture: distribution, feeding, habitation, breeding and population dynamics. Global Journal of Science Frontier Research Interdisciplinary 13(3):6-18.

Sharma HO, Rathi D, Chouhan RS, Meena SC (2013). State of agriculture in Madhya Pradesh. Study No.112. AgroEconomic Research Centre for Madhya Pradesh and Chhattisgarh, Jawaharlal Nehru Krishi Vishwa Vidyalaya, Jabalpur (M.P.)

Shultz S, Baral HS, Charman S, Cunningham AA, Das D, Ghalsasi GR, ... Prakash V (2004). Diclofenac poisoning is wide spread in declining vulture populations across the Indian subcontinent. Proceedings of the Royal Society B (Suppl.) 271:S458-S460.

Simmons RE, Jenkins AR (2007). Is climate change influencing the decline of cape and bearded vultures in southern Africa? Vulture News 56:41-51.

Subedi TR, De Candido R (2013). Population and breeding success of red-headed vulture Sarcogyps calvus and Egyptian vulture Neophron percnopterus in central west Nepal. Vulture News 67(10):21-32.

Subramanya S, Naveein OC (2006). Breeding of long-billed vulture Gyps indicus at Ramanagaram hills, Karnataka, India. Indian Birds 2(2):32-34.

Sutherland WJ, Green RH (2004). Habitat assessment. In: Sutherland WJ, Newton I, Green RH (Eds). Bird ecology and conservation: a handbook of techniques. Oxford: Oxford University Press pp 251-268.

Taggart MA, Senacha KR, Green RE, Jhala YV, Raghavan B, Rahmani AR, ... Meharg AA (2007). Diclofenac residues in carcasses of domestic ungulates available to vultures in India. Environment International 33:759-765.

Thakur ML, Narang SK (2012). Population status and habitat-use pattern of Indian white-backed vulture (Gyps bengalensis) in Himachal Pradesh, India. Journal of Ecology and the Natural Environment 4(7):173-180.

Thakur ML, Kataria RC (2012). Breeding records and nest site preference of Indian white backed vulture in Kangra Valley of Himachal Pradesh, India. International Journal of Science and Nature 3(2):350-353.

van Beest F, van Den Bremer L, De Boer WF, Heitkonig IMA, Monteiro AE (2008). Population dynamics and spatial distribution of Griffon vultures (Gypsfulvus) in Portugal. Bird Conservation International 18:102-117.

Venkitachalam R, Senthilnathan S (2015). Breeding record of Indian vulture (Gyps indicus) in Moyar Valley, Tamil Nadu, India. Current Science 109(2):258-259.

Virani MZ, Monadjem A, Thomsett S, Kendall C (2012). Seasonal variation in breeding Ruppell's vultures Gyps rueppellii at Kwenia, southern Kenya and implications for conservation. Bird Conservation International 22:260-269.

Yamac E (2007). Roosting tree selection of Cinereous vulture Aegypius monachus in breeding season in Turkey. Podoces $2(1): 30-36$.
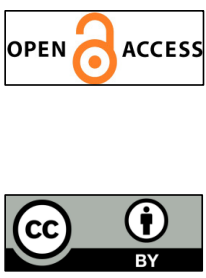

The journal offers free, immediate, and unrestricted access to peer-reviewed research and scholarly work, due SHST supports to increase the visibility, accessibility and reputation of the researchers, regardless of geography and their budgets. Users are allowed to read, download, copy, distribute, print, search, or link to the full texts of the articles, or use them for any other lawful purpose, without asking prior permission from the publisher or the author.

License - Articles published in Notulae Scientia Biologicae are Open-Access, distributed under the terms and conditions of the Creative Commons Attribution (CC BY 4.0) License.

(c) Articles by the authors; SHST, Cluj-Napoca, Romania. The journal allows the author(s) to hold the copyright/to retain publishing rights without restriction. 